\title{
INTERNAL REPRODUCTIVE ORGANS OF Cosmoclopius nigroannulatus (HEMIPTERA: REDUVIIDAE)
}

\author{
JAHNKE, S. M. ${ }^{1}$, REDAELLI, L. R. ${ }^{1}$ and DIEFENBACH, L. M. G. ${ }^{2}$ \\ ${ }^{1}$ Depto. Fitossanidade, UFRGS, Av. Bento Gonçalves, 7712, CEP 91540-000, Porto Alegre, Brazil \\ ${ }^{2}$ IPB-LACEN/RS FEPPS, Av. Ipiranga, 5400, CEP 90610-000, Porto Alegre, RS, Brazil \\ Correspondence to: Luiza Rodrigues Redaelli, Depto. Fitossanidade, UFRGS, Av. Bento Gonçalves, 7712, \\ CEP 91540-000, Porto Alegre, Brazil, e-mail: luredael@ufrgs.br \\ Received May 10, 2004 - Accepted July 8, 2004 - Distributed May 31, 2006
}

(With 3 figures)

\begin{abstract}
The internal reproductive organs of Cosmoclopius nigroannulatus males and females are described, illustrated and measured. No significant difference was registered among immature and reproductive structures of males and their aspect was also similar. However, in females noteworthy differences both in size and aspect were found.
\end{abstract}

Keywords: reduvids, internal reproductive organs.

\section{RESUMO}

\section{Descrição dos órgãos reprodutivos internos de Cosmoclopius nigroannulatus (Hemiptera, Reduviidae)}

Os órgãos internos de reprodução de machos e fêmeas de Cosmoclopius nigroannulatus são descritos, ilustrados e mensurados. Não se registrou diferença significativa entre machos imaturos e reprodutivos quanto ao tamanho das estruturas, sendo o aspecto destas similar em ambos. Já nas fêmeas, constataram-se diferenças notáveis tanto no aspecto quanto no tamanho.

Palavras-chave: reduvídeos, órgãos internos de reprodução.

\section{INTRODUCTION}

Predator insects play an important role in pest regulation in agroecosystems (De Bach \& Rose, 1991). Taking this into account, especially when low impact practices, such as biological control, are pursued their importance increases.

Among predators, reduvids occupy a central position, being associated to various agronomical important cultures as is the case of Montina confusa Stal, a voracious predator of caterpillars, pupa and adults of leaf eater Lepidoptera that damage eucalyptus (Freitas, 1995). The Reduviidae subfamilies Harpactorinae and Zelinae are successful groups due to their reproductive strategies with specializations regarding parental care, copula and egg protection (Louis, 1974; Ambrose \& Livingston, 1988; Vennison \& Ambrose, 1990).
Taking this into account, promising biological control agents in various cultures are pointed out.

Cosmoclopius nigroannulatus Stal (Hemiptera: Reduviidae) is registered as a predator of various pest insects such as aphids, caterpillars and tobacco fleas (Parseval, 1937; Silva et al., 1968; Fallavena, 1993; Caldas, 1998) in tobacco culture. Nymphs and adults feed mainly on nymphs of the tobacco grayish bug, Spartocera dentiventris Berg (Hem.: Coreidae) (Jahnke et al., 2002) and is an important mortality factor of the immature stages as well as teneral adults (Caldas, 1998; Canto-Silva, 1999).

The knowledge about the reproductive status of a population, especially in the case of natural enemies helps when predicting the life history strategies of these organisms and their relationship with prey, considering that the seasonal synchrony is an important factor determining their success as biological control agents (De Bach \& Rose, 
1991; Berryman \& Gutierrez, 1999). A detailed acquaintance of the reproductive system of the species involved represents a condition for this comprehension. The aim of the present work is to illustrate the internal reproductive organs of males and females of C. nigroannulatus.

\section{MATERIAL AND METHODS}

The field work was carried out in a tobacco culture at the experimental area of the Departamento de Fitossanidade, Universidade Federal do Rio Grande do Sul, in Porto Alegre $\left(30^{\circ} 01^{\prime} \mathrm{S}\right.$ and $\left.51^{\circ} 13^{\prime} \mathrm{W}\right)$. At the beginning of August, 1999, 270 tobacco seedlings of Nicotiana tabacum L. (Solanaceae) were planted in ten rows in an area of approximately $300 \mathrm{~m}^{2}$.

Weekly collections of adults and $5^{\text {th }}$ instar nymph began when the presence of egg masses and nymphs of $C$. nigroannulatus were first registered in the study area. Nymphs were kept in laboratory conditions $\left(25^{\circ} \mathrm{C} \pm 2{ }^{\circ} \mathrm{C}\right.$ and $70 \pm 5 \% \mathrm{RH})$, individualized in clear plastic pots $(15 \mathrm{~cm} \varnothing$ and $9 \mathrm{~cm}$ height) and fed daily on S. dentiventris nymphs until they reached the adult stage.

Just after being captured in the field, the C. nigroannulatus adults were killed with ethyl acetate fumes and dissected in ethyl alcohol with the aid of a stereomicroscope Wild M5. Measurements were taken using a micrometer reticule coupled to the ocular, and illustrations with the aid of a camera lucida to characterize the internal reproductive organs of males and females.
The adults obtained from the nymphs reared in the laboratory were dissected soon after being emerged in the same way.

The measurements of immature and reproductive individuals were compared using the ANOVA and Tukey test.

\section{RESULTS AND DISCUSSION}

\section{Male organs (Fig. 1)}

A pair of kidney-shaped testes $(\mathrm{T})$ lies at the sides of the alimentary tract, approximately in the middle of the abdominal cavity. Each testis is wrapped by an orange membrane, which is already noticed in freshly emerged adults. This peritoneal investment enveloping the testis as a whole constitutes the scrotum (Imm, 1970). A vas efferens (VE) leaves each testis from its middle region, originating the epididymis (E). Each epididymis is also wrapped by a membrane of orange coloration and is continued by a vas deferens (VD). In C. nigroannulatus there is no enlargement of the duct in the shape of a dilatation (vesicula seminalis). A pair of accessory glands (AG), formed by four filaments, originates at the distal end of the reproductive system. In the final portion of the system the vasa deferentia originates a short ductus ejaculatorius (DE), where the accessory glands open.

There was no significant difference between immature and reproductive individuals regarding the testis length and width average values (Table 1), respectively: $\mathrm{F}=0.01613, \mathrm{P}=0.8039$ and $\mathrm{F}=1.6694, \mathrm{P}=0.2239$. This finding may indicate that the male reproductive system is already mature when the emergence occurs. In insects,

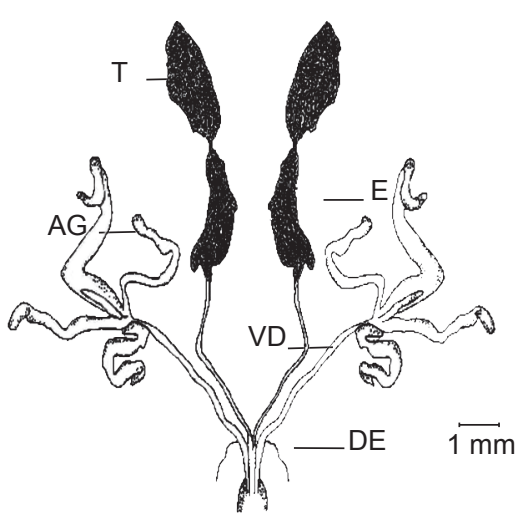

Fig. 1 - Male internal reproductive organs of Cosmoclopius nigroannulatus Stal, dorsal view. DE - ductus ejaculatorius; E - epididymis; AG - accessory gland; T - testes; VD - vas deferens; and VE - vas eferens. 
the spermatogenesis generally takes place during the immature stages. In adults, the spermatozoa already generally leave the testis (Imms, 1970). Furthermore, as pointed out earlier, the coloration of the testis wrapping membrane (scrotum) does not vary between freshly emerged males and mature ones.

\section{Female organs (Fig. 2 and 3)}

A pair of ovaries, each one formed by seven ovarioles (OV) of the meroistic teletrophic type (Chapman, 1985), is positioned laterally in the abdominal cavity. In reproductive females, the ovary average length and width is approximately two times larger than in the immature ones (Table 1). The number of oocytes in reproductive females varied from 16 to 35 per ovary. They are conspicuous and present a brownish coloration towards the terminal portion of the ovariole. In immature females they are not discernible. Each ovariole opens through a pedicel in the calix of the lateral oviduct (LO). The lateral oviducts, in reproductive females, are approximately 1.3 times larger in length than those of the immature ones. They join in the middle line of the abdominal cavity, forming the common oviduct (CO) which is very short relative to the total size of the reproductive system. The common oviduct is approximately 1.5 times longer and 1.4 times wider when compared to those of the immature ones. The larger measurements registered in the ovaries, lateral oviducts and common oviduct in reproductive females are associated to the ripening of the oocytes and the beginning of oviposition.

The common oviduct opens ventrally to the genital chamber (GC). The oocytes leave the terminal portion of the ovariole towards the lateral oviduct and are fertilized when going through the genital chamber. The $C$. nigroannulatus females do not have spermatheca or even a pseudospermatheca. According to Davis (1969), Harpactorinae females

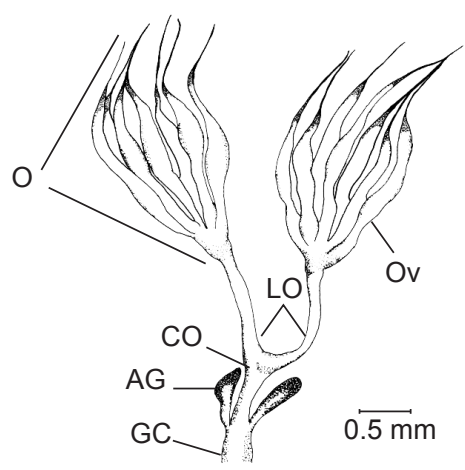

Fig. 2 - Female internal reproductive organs of a sexually immature specimen of Cosmoclopius nigroannulatus Stal, dorsal view. AG - accessory gland; GC- genital chamber; CO - common oviduct; LO - lateral oviduct; O - ovary; and Ov - ovariole.

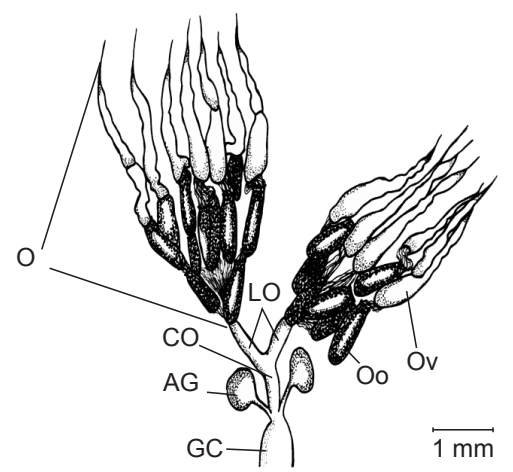

Fig. 3 - Female internal reproductive organs of a sexually mature specimen of Cosmoclopius nigroannulatus Stal, dorsal view. AG - accessory gland; GC- genital chamber; CO - common oviduct; LO - lateral oviduct; O - ovary; Oo - oocyte; and Ov - ovariole. 
TABLE 1

Average measurements of length and width $(\mathrm{mm})$ of internal reproductive system structures of Cosmoclopius nigroannulatus. Reproductive, females $(n=9)$ and males $(n=8)$; immature, females $(n=12)$ and males $(n=8)$.

\begin{tabular}{|l|c|c|c|c|}
\hline \multicolumn{1}{|c|}{ Structure } & \multicolumn{2}{|c|}{ Immature } & \multicolumn{2}{c|}{ Reproductive } \\
\hline & Length & Width & Length & Width \\
\hline Ovary & $2.240 \pm 0.255$ & $0.875 \pm 0.134$ & $5.573 \pm 0.513$ & $2.233 \pm 0.225$ \\
\hline Lateral oviduct & $1.582 \pm 0.116$ & $0.248 \pm 0.052$ & $2.146 \pm 0.309$ & $0.366 \pm 0.030$ \\
\hline Common oviduct & $0.740 \pm 0.060$ & $0.297 \pm 0.045$ & $1.088 \pm 0.162$ & $0.426 \pm 0.032$ \\
\hline Accessory gland & $0.600 \pm 0.162$ & $0.393 \pm 0.033^{*}$ & $1.022 \pm 0.197$ & $0.288 \pm 0.085^{*}$ \\
\hline Testes & $2.54 \pm 0.097^{*}$ & $1.42 \pm 0.316^{*}$ & $2.666 \pm 0.065^{*}$ & $1.40 \pm 0.071^{*}$ \\
\hline
\end{tabular}

*No significant $(\mathrm{P}>0.005)$.

either present a much reduced or no spermatheca at all.

A pair of accessory glands (AG) opens in the proximal portion of the genital chamber laterally relative to the common oviduct. In reproductive females, these glands acquire a globose shape.

Significant differences between immature and reproductive female measurements were found regarding almost all organs considered: ovary (length, $\mathrm{F}=282.28, \mathrm{P}=0.0002$; width, $\mathrm{F}=215.94, \mathrm{P}=0.0001$ ); lateral oviduct (length, $\mathrm{F}=25.35, \mathrm{P}<0.0001 ;$ width, $\mathrm{F}=21.19, \mathrm{P}=$ 0.0005 ); common oviduct (length, $\mathrm{F}=24.89$, $\mathrm{P}=0.0002$; width, $\mathrm{F}=35.85, \mathrm{P}<0.0001)$ and accessory gland (length, $\mathrm{F}=20.51, \mathrm{P}=0.0006$ ). A significant difference relative to the width of the accessory gland $(\mathrm{F}=11.24, \mathrm{P}=0.0052)$ was not registered.

These results show that $C$. nigroannulatus females need a time interval to mature their reproductive organs after emergence. This may be explained by the fact that in many insect species, the vitelogenesis only occurs after the female feeds (Snodgrass, 1935). This fact corroborates with what Fallavena (1993) found, who registered a preoviposition period varying from 11 to 38 days for C. nigroannulatus females.

\section{REFERENCES}

AMBROSE, D. P. \& LIVINGSTON, D., 1988, Ovipositional behaviour in assassin bugs (Insecta: Reduviidae) Environ. \& Ecol., p. 48-58.

BERRYMAN,A.A., GUTIERREZ,A., 1999, Dynamics of insect predator-prey interactions. pp. 389-417, In: C. B. Huffaker, P. Gutierrez. Ecol. Entom. 2. ed. New York: John Wiley \& Sons.

CALDAS, B. C., 1998, Ciclo Biológico de Corecoris dentiventris Berg, 1884, (Heteroptera, Coreidae) em cultura de fumo e morfologia das fases juvenis. Porto Alegre, 93f. Dissertação (Mestrado em Fitotecnia) - Universidade Federal do Rio Grande do Sul, Porto Alegre.

CANTO-SILVA, C. R., 1999, Aspectos da dinâmica populacional e distribuição espacial de Corecoris dentiventris em cultivo de Nicotiana tabacum. Porto Alegre, 167f. Dissertação (Mestrado em Ecologia) - Universidade Federal do Rio Grande do Sul, Porto Alegre.

CHAPMAN, R. F., 1985, The insects structure and function. $3^{a}$ ed. New York, American Elsevier, 819p.

DAVIS, N. T., 1969, Contribution to the morphology and phylogeny of the Reduvioidea. Part IV. The harpactorinae complex. Ann. Entomol. Soc. Am., 62: 74-94.

DE BACH, P., ROSE, D., 1991, Biological control by natural enemies 2. ed. New York: Cambridge, 440p.

FALLAVENA, M. T. B., 1993, Aspectos Biológicos e Morfológicos de Cosmoclopius nigroannulatus (Stal, 1860) (Hemiptera, Reduviidae, Zelinae) Porto Alegre, 96f. Dissertação (Mestrado em Zoologia) - Pontifícia Universidade Católica do Rio Grande do Sul, Porto Alegre, 1993.

FREITAS, S., 1995, Capacidade de predacão, sobrevivência e ciclo biológico do predador Montina confusa (Hem.: Reduviidae) alimentado com lagartas da broca da cana de açúcar. An. Soc. Entom. Bras., 24(2): 195-199.

IMMS, A. D., 1970, A general textbook of entomology. London: Methuen, 886p.

JAHNKE, S. M., REDAELLI, L. R., DIEFENBACH, L. M. G., 2002, Population dynamics of Cosmoclopius nigroannulatus Stal (Hem.; Reduviidae) in tobacco culture. Rev. Bras. Biol., 62(4B): 819-826.

LOUIS, D., 1974, Biology of Reduviidae of Cocoa Farms in Ghana. The Amer. Midl. Natur., 91(1): 68-89.

PARSEVAL, M. 1937. As pragas do fumo no Rio Grande do Sul. Chácaras e Quintares, 56: 489-494.

SNODGRASS, R. E. 1935. Principles of insect morphology. New York: McGraw-Hill Book Company, 667p.

SILVA, A. G. D. A. et al., 1968, Quarto catálogo dos insetos que vivem nas plantas do Brasil, seus parasitos e predadores. Parte II, 1 tomo. Rio de Janeiro, Ministério da Agricultura, 622p.

VENNISON, S. J. \& AMBROSE, D. P., 1990, Diversity of eggs and ovipositional behaviour in Reduviids (Insecta: Reduviidae) of south India. Mitt. Zool. Mus. Berl. 66(2): 319-331. 